\title{
Language Choice of Balinese and Japanese Mixed Marriage Children
}

\author{
Lukia Zuraida \\ Bali Tourism Polytechnic, Bali, Indonesia \\ Made Budiarsa \\ Udayana University, Bali, Indonesia \\ I Ketut Darma Laksana \\ Udayana University, Bali, Indonesia \\ I Wayan Simpen \\ Udayana University, Bali, Indonesia
}

\begin{abstract}
Japanese and Balinese mixed marriage children have become bilingual since the early years of the language acquisition period. They acquired the inheritance of the languages (Indonesian, Japanese, and Balinese) from their parents. This research was conducted to find the language choice of mixed marriage children of Balinese and Japanese in Bali. The language use domain is divided into two: family and social. In each domain, the topic, the background of the situation, and the people involved are determined. The data was gathered using questionnaires employed to 10 mixed married families. The method includes observation and interviews. The result of data analysis showed that in the family domain there are variations of the children's language preferences when communicating. The children choose Indonesian when communicating with the father, and Japanese with the mother. However, there are also other options for using mixed code between Indonesian, Japanese and also English. In the social domain, the language choice is more homogeneous, which is Indonesian. Meanwhile, it was found that there was resistance towards the use of Balinese by JapaneseBalinese Mixed Marriage Family (JBMF) and the factors that affected the children's language choice were also discovered.
\end{abstract}

Index Terms - mixed marriage, language choice, language use domain

\section{INTRODUCTION}

\section{A. Background}

Different nations, cultures, and languages on mixed marriages cause cross-contact of the three aspects. The cultural and language contacts in mixed marriage communication are unavoidable and a very interesting linguistic phenomenon. Due to the circumstance, the linguistic situation will vary because it involves more than one language.

Children from mixed marriages who are exposed to different cultures and languages become an interesting subject to be studied. Language acquisition in a bilingual situation will certainly lead to different linguistic phenomena. The children simultaneously acquire bilingual (McLaughlin's, cited in Shin, 2005). A general terminology of bilingual acquisition could be the 'simultaneous acquisition of more than one language during the period of primary language development' (Genesee, 1989, p.162). The acquisition of two languages has been dubbed BFLA (Meisel, 1989, p. 20).

The purpose of this research is to explain the language choice of BFLA children from mixed-marriage between Balinese fathers and Japanese mothers. The children of Japanese-Balinese mixed-marriage families (hereinafter called JBMF), who live in Bali, since the beginning of their language acquisition have been introduced to two different languages from both parents.

The families live in Bali and have no difficulties in adapting and communicating with their social environments. Language choice is strongly affected by the social environment a bilingual person is exposed to (Katja, 2007). Indonesian language (IL) is the dominant language used by the community in the neighborhood of JBMF. Although the location of the research is in Bali with Balinese Language (BL) as a regional language, in the urban areas IL as the national language is more widely used.

\section{B. Language Options in Language Use Domain}

According to Fasold (in Rokhman, 2013, p. 25), the selection of language used is not as simple as we thought, i.e. choosing a whole language in a communication event. Imagine a person who speaks two or more languages must choose the language he or she will use. Grosjean $(1998$, p. 134) proposes to analyze it by looking at which language is used with whom and for what. 
In language selection, there are three categories of options. First, by selecting one variation of the same language (intra language variation). Second, by code-switching; using one language for one need and another for other needs in a single communication event. Third, by interfering with code-mixing; using a specific language of mixed fragments from other languages (Fasold, 1986 ).

According to Romaine (1995), the language choice is not arbitrary and not all speakers are doing the same thing. Through their language choice of preferring one language to another or using a variation of the same language, the speaker is showing what might be called "Act of Identity"; choosing which group the speaker wants to be recognized.

According to Fishman (1972), the domain is a certain institutional context where a variety of languages is more appropriate than others. The use of language in the context of bilingualism depends on the domain of the conventional institution of the spoken society.

The topics of discussion are modern and traditional. Modern topics relate to present and future orientation. In the etymology perspective, modern means the present, new models and not ancient. The traditional topic is the opposite, which refers to something that is oriented in the past, such as ways of doing things inherited by the ancestors.

Language choices in bilingual/multilingual community social interactions are caused by a variety of social and cultural factors. Ervin-Tripp (1972) identifies four major factors as language choice markers of speakers within the social interaction, namely (1) the setting (time and place) and the situation, (2) participants in the interaction, (3) topics of conversation, and (4) the function of interaction.

\section{Object of Investigation}

Mixed marriage in this study refers to marriages between Balinese and Japanese people living in Bali. More specifically, the mothers are Japanese and the fathers are Indonesian with Balinese ethnic. The families live in the province of Bali and have children of both boys or girls with the age ranging between 7 to 20 years old.

The object of this research is the children of mixed marriages, who since the early years of language acquisition have been exposed to two languages: Japanese (JL) and Indonesian (IL). The research took place in Bali, where the families of mixed marriages live. To gain the necessary data, an observation of the $10 \mathrm{JBMF}$ families with children was conducted. The object of the research is following the determined criteria of the respondents. The research is carried out in a social environment such as home, school or neighborhood. The domain of language use is divided into 2: family and social domains.

\section{CORPUS AND METHODS}

\section{A. CORPUS}

The data is gathered by providing questionnaires to all members of JBMF. The questionnaires are filled by both fathers and mothers, and their children. The data from the questionnaires consist of family's biodata, language proficiency, and language usage. JBMF's language skills include Indonesian (IL), Japanese (JL), Balinese (BL), and English (EL).

The language use domain differs into two: family and social domains. Each domain is divided into interlocutors, topics of discussion, and situation. In the neighborhood domain, the interlocutor is grouped into three, namely older neighbor $(\mathrm{ON})$, peer neighbor $(\mathrm{PN})$, and younger neighbor $(\mathrm{YN})$. Meanwhile, the situation background is differentiated into three situations: casual, serious and emotional. Within the family domain, the language used between the married couples (husband and wife), children and parents, JBMF to the husband or wife's family, and other family members are being observed.

The topic of conversations in the social domain is limited to three variables, whilst, in the family domain is 4 variables. The topics in the social domain consist of (1) General/News/TV, (2) traditional ceremonies, and (3) official. The situation background is divided into 3: (1) formal, (2) casual, and (3) emotional, whereas, the topics on the family domain consist of (1) households, (2) traditional ceremonies, (3) official matters, and (4) advice. Background situation when the communication event takes place is divided into three: (1) formal, (2) casual, and (3) emotional.

The following topics of discussion are identified in the corpus:

- Language choice in the social domain

- Affecting factors of language preference in the social domain

- Language choice in the family domain

- Affecting factors of language preference in the family domain

The choice of language used by JBMF is strongly influenced by the interlocutors, topics of discussions, and situations during the conversations. This research aims to see the choice of language within the language use domains of various topics, interlocutors, and background situations of each respondent.

\section{B. Methods}

The research is located in Bali, where the object of the study is living. To obtain the necessary data, observations were carried out to 10 families of mixed marriages with children who full fill the determined criteria of respondents. The research is conducted in a social environment of the research object such as at home, school or neighborhood residence. In addition to direct observations, the data is also taken through video recording and voice recording. 
A nonprobability sampling technique was used to determine the sample. This sampling technique does not provide equal opportunities for each element or population member to be selected as a sample (Sugiyono, 2010). The sampling technique used purposive sampling.

\section{DISCUSSION}

The analysis combines a quantitative approach with a qualitative and analytical one (see Rossman and Wilson, 1985). The data includes the frequency of the use of IL, JL, BL, and EL. To make identifying easier, a table of recapitulation is presented in this paper. Each variable in the questionnaire is identified to get an overview of the factors that influence the language choice of the children. Some of the variables are the influence of the strategy of language transmission from parents to children, mother tongue (MT), language used in the family, the dominant language in the environment where the family resides and other variables.

The language choice of language use domain will be analyzed using the theory proposed by Fishman (1972). A domain is a specific institutional context where the varieties are more precisely used than others. The use of language in the context of bilingualism depends on the domain of conventional institutions within the spoken society. Domains are constellations of topics, situations, settings, and participants. Ervin-Trip (1972) also states that there are four languageselection markers used by the speakers i.e., 1) settings and situations, 2) engagement/participants, 3) topics of discussion and an addition of another function, which is 4) interaction functions.

The choice of language used by JBMF is strongly influenced by the factors of the interlocutor, the topic, and the situation of the conversation. The language use domain is divided into family and social domains. The interlocutors in the family domain are the father/husband, mother/wife, the child, family of both parents, and other family members who are living in their house. Meanwhile, the interlocutors of the social domain are JBMF's interactions with older neighbors $(\mathrm{ON})$, peer neighbors (PN), and younger neighbors (YN) that occur in the neighborhood, schools, and other public areas. The topics of discussion are divided into general, traditional ceremonies, religions, and households. The functions of interaction are advising, casual, formal, and emotional communications. Specifically, the topic of discussion within the social domain is specified into 3 variables, namely, (1) General/News/TV, (2) traditional ceremonies, and (3) official matters, whilst, in the family domain, there are 4 variables used as topic of discussion, which cover: (1) household, (2) traditional ceremonies, (3) official matters, and (4) advising. The background situation in both domains is specified in 3 situations, such as (1) serious, (2) casual and (3) emotional.

\section{A. Children's Language Choice in the Social Domain}

In the social domain, the interlocutors are older neighbors, peer neighbors, and younger neighbors. The preferred languages are Indonesian (IL), Japanese (JL), Balinese (BL) and English (EL).

The frequency of language choice in the social domain is shown in Table 1.

TABLE 1

LANGUAGE CHOICE IN NEIGHBORHOOD DOMAIN

\begin{tabular}{|c|c|c|c|c|}
\hline No & $\begin{array}{l}\text { Interlocutor } \\
\text { Topic }\end{array}$ & $\mathrm{ON}$ & $\mathrm{PN}$ & YN \\
\hline 1 & General/TV news & IL $(100 \%)$ & $\begin{array}{c}\text { IL (80\%) } \\
\text { IL \& BL (20\%) }\end{array}$ & $\begin{array}{c}\text { IL(90\%) } \\
\text { IL\& BL }(10 \%)\end{array}$ \\
\hline 2 & Traditional & IL $(100 \%)$ & $\begin{array}{c}\text { IL }(90 \%) \\
\text { IL \& BL(10\%) }\end{array}$ & $\begin{array}{c}\text { IL(90\%) } \\
\text { IL \& BL }(10 \%)\end{array}$ \\
\hline 3 & Casual & IL $(100 \%)$ & IL $(100 \%)$ & IL $(100 \%)$ \\
\hline 4 & Serious & IL (100\%) & IL (100\%) & IL (100\%) \\
\hline 5 & Emotional & IL (100\%) & IL (100\%) & IL (100\%) \\
\hline
\end{tabular}

All the children choose IL when the interlocutor is ON. However, when communicating with PN in general topic or news, the respondents who prefer to use only IL is $80 \%$, while the $20 \%$ choose IL and BL. Meanwhile, during their conversation with YN, 90\% use Indonesian and 10\% use a mixed code of IL and BL. For the topic of traditional ceremonies, the choice of language when communicating with PN and YN interlocutors shows the same result. $90 \%$ of the children choose IL and 10\% choose IL and BL. For serious, casual, and emotional situations, the choice reaches $100 \%$ for all interlocutors. From the explanation above, it can be seen that the choice of IL dominates in the social domain. The children mostly use IL to all interlocutors and in all situations.

\section{B. Affecting Factors of Language Preference in the Social Domain}

The option for IL within the social domain in almost all variables with all interlocutors is influenced by several factors i.e.: IL as the state language, the interlocutors, the purpose of the communication, and the function of the interaction.

a) Indonesian as a State Language

In addition to using the language of each region, Indonesians also use IL in daily interactions. Similarly, in Bali, the people use IL in the official domains and still use BL as a regional language in other domains. The respondents of this study (JBMF) are living in urban areas with heterogeneous communities such as different ethnic groups, languages and even citizenship. IL has become the main language used for interactions among the people, to facilitate communication 
with other heterogeneous members of the community. The neighborhood of JBMF residence is a heterogeneous urban and its people are not only Balinese. Therefore, to achieve the purpose of good communications, the choice of IL becomes very rational. By using a language that is understood by everyone in the community, the final purpose of communication will be achieved.

b) Interlocutor

The interlocutors in the social domain are YN, PN, and ON. There are differences in language choice by the children. When they speak with ON 100\% are using IL for all topics and situations; with PN, 20\% choose IL and BL, while $80 \%$ choose IL; and with YN 90\% choose IL and 10\% choose IL and BL. For traditional topics with PN and YN as interlocutors, the number showed the same result. $90 \%$ choose only IL and 10\% choose IL and BL. When the settings of the situation are casual, formal and emotional all choose IL (100\%) with all interlocutors.

c) Purpose

According to Keraf (1997, p. 1), a language is a communication tool between members of the community in the form of sound symbols produced by the human's instrument. The selection of IL by JBMF's children in the social domain or outside their home has the purpose of delivering their intention and ideas to be understood by the interlocutors. The dominant language used within JBMF residential environment is IL. All members of the public understand and use IL as a tool to communicate. The use of IL makes the purpose of communication with the communities in the living environment can easily be accomplished and the ideas can be well conveyed.

d) Interaction's Function

Language has certain functions that are used based on the needs of a person. The language function is used as a tool to express themselves, a tool to communicate, a tool to integrate and adapt socially in the environment or certain situations, and as social control (Keraf, 1997, p. 3). The interaction's function in the community can be a way of delivering information, solicitation, or routine of habits such as greeting, apologizing or thankful expressions. The aspects of the interaction's function include positioning the social status, create social distances, involving others in speech, ruling or pleading. The interaction of JBMF's children in the social domain, which is dominated by the use of IL, indicates the desire to be accepted by the community.

\section{Language Choice in Family Domain}

Language choices in the family domain are differentiated by the topic and interlocutor. The topics consist of three variables: household, traditional ceremonies, and advice. The interlocutors involve husbands, wives, children, grandparents, and other family members who are living together in the same house. Meanwhile, the background situation is divided into three: casual, formal and emotional moments.

The JBMF's children are BFLA and influenced by two different languages from both parents. Their language is more diverse than both parents. The following data shows the choice of the children's language in the family domain. The interlocutors are all family members.

TABLE 2

LANGUAGE CHOICE IN FAMILY DOMAIN

\begin{tabular}{|c|c|c|c|c|c|c|}
\hline No & $\begin{array}{c}\text { Interlocutor } \\
\text { Topic }\end{array}$ & Mother & Father & $\begin{array}{c}\text { Family of } \\
\text { mother }\end{array}$ & Family of father & $\begin{array}{l}\text { Another } \\
\text { family } \\
\text { member }\end{array}$ \\
\hline 1 & Household & $\begin{array}{c}\text { JL (70\%) } \\
\text { IL/JL }(30 \%)\end{array}$ & $\begin{array}{c}\text { IL (90\%) } \\
\text { IL/JL }(10 \%)\end{array}$ & JL (100\%) & IL (100\%) & IL \\
\hline 2 & $\begin{array}{l}\text { Traditional } \\
\text { ceremony }\end{array}$ & $\begin{array}{c}\text { JL }(70 \%) \\
\text { IL }(10 \%) \\
\text { IL/JL }(20 \%)\end{array}$ & IL $(100 \%)$ & JL (100\%) & IL $(100 \%)$ & IL \\
\hline 5 & Casual & $\begin{array}{c}\text { JL (70\%) } \\
\text { IL }(10 \%) \\
\text { IL/JL }(10 \%) \\
\text { IL/JL/EL }(10 \%)\end{array}$ & IL $(100 \%)$ & JL (100\%) & IL $(100 \%)$ & IL \\
\hline 7 & Emotional & $\begin{array}{c}\text { JL }(70 \%) \\
\text { IL }(10 \%) \\
\text { IL/JL }(10 \%) \\
\text { IL/JL/EL }(10 \%)\end{array}$ & IL $(100 \%)$ & JL (100\%) & IL (100\%) & IL \\
\hline
\end{tabular}

In communicating with family members, the languages used are IL, JL, as well as mixed codes IL and JL, and EL. When the mothers are the interlocutors, the languages involved are JL, IL, EL or mixed codes of these 3 languages. However, when the fathers act as the interlocutors, IL is mostly chosen, although there is also a choice of mixed codes of IL and JL. When the children communicate with a family member from their fathers' side, they choose only IL. 
Similarly, when communicating with their mothers' family members, then the option is only JL.

TABLE 3

THE AVERAGE OF CHILDREN'S LANGUAGE CHOICE IN THE FAMILY DOMAIN

\begin{tabular}{|c|c|c|c|c|c|c|}
\hline No & $\begin{array}{c}\text { Interlocutor } \\
\text { Language }\end{array}$ & Mother & Father & $\begin{array}{c}\text { Family of } \\
\text { mother }\end{array}$ & $\begin{array}{c}\text { Family of } \\
\text { father }\end{array}$ & $\begin{array}{c}\text { Other } \\
\text { family } \\
\text { members }\end{array}$ \\
\hline 1 & IL & 8,33 & 98,33 & 0 & 100 & 3 \\
\hline 2 & $\mathrm{JL}$ & 70 & 0 & 100 & 0 & 0 \\
\hline 3 & $\mathrm{IL} / \mathrm{JL}$ & 8,33 & 1,67 & 0 & 0 & 0 \\
\hline 4 & $\mathrm{IL} / \mathrm{JL} / \mathrm{EL}$ & 6,7 & 0 & 0 & 0 & 0 \\
\hline
\end{tabular}

The language involved during the communication in the family domain consists of four language varieties, i.e. IL, JL, $\mathrm{IL} / \mathrm{JL}$, and $\mathrm{IL} / \mathrm{JL} / \mathrm{EL}$. When the interlocutors are the mothers, the language choice that falls into JL is $70 \%$. IL and mixed code of IL/ JL has the same percentage of $8,3 \%$, and the mixed code of IL/ JL/EL is $6,7 \%$. When the interlocutors are the fathers, IL dominates the choice with the percentage of $98,3 \%$, whilst, the rest of $1,67 \%$ uses a mixed code of IL/ JL. Since the family of the mothers is entirely Japanese, their choice of language is to use JL (100\%). Similarly, when communicating with the family of the fathers, who are Balinese, then the choice is IL (100\%). In the family domain, the children do not choose BL.

\section{Affecting Factors of Language Preference in the Family Domain}

Affecting factors of a child's language preference in the family domain are: the dominant language in the environment, interlocutor, the cultural background, the attitude to the mother tongue, and the gender.

a) The dominant language in the community

All JBMF respondents are living in urban areas with homogeneous community members. The community members consist of various ethnicities. Each ethnic has its regional language. Therefore, the use of IL in such an environment is the most appropriate choice by all parties. The children of JBMF also choose to use IL when communicating with the family except with their mothers or the mothers' families. The choice of IL is more dominant than the other languages. The choice of IL aims to allow communication to run smoothly and can be accepted by all parties.

b) Interlocutor

JBMF children's communication in the family domain is unique. When the interlocutor is their mothers, the choice of $\mathrm{JL}$ is $70 \%$. Whereas, when the interlocutor is their fathers then they replace the language by choosing IL with a very large percentage, which is $98.33 \%$. The choice is $100 \%$ for $\mathrm{IL}$ when the interlocutor is a member of the fathers' family and $100 \%$ for JL when the interlocutor is their mothers'. None of them chooses BL for the reason of the inability to speak Balinese and the difficulties to study BL. Even though in a situation where a father's family is living in the same house with them, they do not use BL but choose to use IL.

c) Cultural background

In JBMF families, the children are raised with two different cultures; from their fathers and mothers. They learn the way of living as Balinese within the traditional community from their fathers, but the mothers also teach their children Japanese culture. As eastern cultures, both Balinese and Japanese have the same principles. Both cultures embrace the principle of social culture that has a similar resemblance to a family relationship, a living value, and a harmonious life purpose. Language choices in the family domain show tolerance of the eastern cultures and can easily be adapted to different groups. Every child selects a language that corresponds to the audience so the needs of the listeners can be fulfilled.

d) Attitudes towards mother tongue

Attitudes toward the mother tongue influence the choice of language by each respondent. The maternal awareness regarding the inheritance of language to the children reflects the attitude of maintaining the mother tongue within the family. The results from the questionnaires show that all mothers of JBMF still use JL and consider it important to teach $\mathrm{JL}$ to her children. In addition to communicating using $\mathrm{JL}$ at an early age, mothers also consider the importance of sending their children to a special school that teaches Japanese and its culture. The most prominent reason is that so the children can communicate with their maternal family in Japan and they do not forget their roots as heirs of the Japanese blood.

Although their fathers' mother tongue is Balinese, however, since IL is a state language, when they communicate with the children the language used is IL (93\%). Unfortunately, there is no choice for BL. It is closely related to the language politics in Indonesia that the regional language is a second language, while the state language is IL. Nevertheless, husbands or fathers still use BL when talking to their parents. Two JBMF respondents who lived with their husbands' mothers continue to choose BL as a communication tool. The choice of using BL lesser than IL is caused by many factors. Mostly the reason is that the dominant language in the community is IL and some of the respondents also assume that their mother tongue is IL.

e) Gender

In eastern culture, the man is the family leader. The role of a man or father as the head of the family has the obligation to give livelihood to the family. Whereas, the role of a woman or mother in the eastern culture is a 
companion to family care. Mother has more roles in family domestic affairs. As a consequence of this role, the husband is more doing the work outside their home and the wife is more at home taking care of the family. Mother has a great role in transmitting language to her children. It is known that the choice of mother tongue when communicating with the children is dominated by JL (75\%), and the rest falls into a mixed code of IL/ JL. All mothers in JBMF families see the importance of teaching JL to their children. From an early age, the children are accustomed to learning Japanese and its culture through language courses, television, videos, and other media. All the children respondents can speak JL properly and can read hiragana, katakana, and kanji. The husband, whose mother tongue is Balinese and Indonesian, when communicating with the children mostly use IL (93.3\%), while the rest consists of IL/JL mixed code. No choice falls into BL. Children also learn IL from the community, neighborhood, and school.

\section{CONCLUSION}

From the explanation above, it can be concluded that there is no sole factor affecting the choice of language. All factors influence the choice of language at the same time. From the JBMF family case, the most influential factor is the social environment and interlocutor factors. JBMF is living in the community where IL is dominating, therefore, in the social domain, the option for language choice of communication to all interlocutors and in all situations falls into IL. In the family domain, the most influencing factor is the interlocutor. When the interlocutors are the father and his family, almost $100 \%$ of the children's language chooses IL. Meanwhile, if the interlocutors are the mother and her family, the option falls into JL. In conversations between the mothers and children, JL is mostly selected (75\%). Likewise, when the communications occur between the husband, children or the wife's family, the choice of JL and EL appear.

Language choice is a reasonable constellation for a bilingual. With their language ability, they can choose the appropriate language when communicating. Every language selection is inseparable from the domain usage, the situation setting and the topic of discussion. In the social domain, the children of JBMF prefer to use IL. With older neighbors, the choice of language use is IL with $100 \%$. IL remains the dominant choice when communicating with peers and to younger people. The factors that influence language choice in the social domain are IL as the state language, interlocutor, purpose, and interaction function. In the family domain, language choices vary more. There are choices for IL, JL, BL, and EL. When the interlocutor is the father, the choice of language is IL and mixed codes IL/JL and none for BL. When communicating with the mother, the choice of JL is $70 \%$. There are choices on IL and mixed codes of IL/JL/EL. When the interlocutor is a family from their father's side, all children use IL, and with the Japanese family, they use JL. The language choice of the children in the family domain is influenced by five factors. These factors are the dominant language in the community, interlocutor, cultural background, attitudes toward mother tongue, and gender. Out of all languages, none falls into Balinese, which is the mother tongue of the fathers. The fathers use IL more often when communicating with the children, which is done intentionally for specific reasons. The mothers cannot speak Balinese but they can speak IL. Therefore, the choice for IL becomes the most acceptable one for all parties. The usage of Balinese has decreased significantly. It is proven by the findings that BL is not chosen by the children when communicating with all interlocutors in both domains.

\section{APPENDIX. ABBREVIATION}

$\begin{array}{llcl}\text { JBMF } & \text { Japanese Balinese Mixed Marriage Family } & \text { IL } & \text { Indonesian Language } \\ \text { BB } & \text { Balinese Language } & \text { EL } & \text { English Language } \\ \text { PN } & \text { Peer Neighbor } & \text { YN } & \text { Younger Neighbor } \\ \text { BFLA } & \text { Bilingual first language acquisition } & & \end{array}$
JL Japanese Language
ON Older Neighbor

\section{ACKNOWLEDGMENTS}

The authors would like to thank Bali Tourism Polytechnic for supporting the research.

\section{REFERENCES}

[1] Chaer, A. (2003). Sosiolinguitik: Perkenalan Awal. Jakarta: Rineka Cipta

[2] Ervin-Tripp, Susan. (1972). "On sociolinguistic rules: Alternation and co-occurrence: In: Directions in sociolinguistics, (eds.) John J. Gumperz dan Dell Hymes. New York, Holt, Rinehart and Winston, 213-250

[3] Fasold, R. (1986). The Sociolinguistics of Society.New York: Brasil Blackwell.

[4] Fishman, J. (1972). The Sociology of Language: An Interdisiplinary Social Science Approach to Sociolinguistic. Rowley Mass: Newbury House.

[5] Genesee, Fred. (1989). “Early bilingual development: one language or two?”. Journal of Child Language 16, 161-179.

[6] Grosjean, François. (1998). "Studying bilinguals: methodological and conceptual issues". Bilingualism 1, 131-149.

[7] Katjaf, C. (2007). "Code Switching in Bilingual Children", Studies in Theoretical Psycholinguistics, Vol. 37. Nederland: Springer.

[8] Keraf, G. (1997). Komposisi. Jakarta: Ikrar Mandiri Abadi.

[9] Meisel, Jürgen M. (1989). "Early differentiation of languages in bilingual children". In Hyltenstam \& L.K. Obler (eds.), Bilingualism across The Lifespan: Aspects of Acquisition, Maturity and Loss. Cambridge: Cambridge University Press, 13-40.

[10] Rokhman, F. (2013). Sosiolinguistik, Suatu Pendekatan Pembelajaran Bahasa dalam Masyarakat Multikultural. Yogyakarta: 
Graha Ilmu.

[11] Romaine, S. (1995). Bilingualism. $2^{\text {nd }}$ ed. Oxford: Blackwell Publishers.

[12] Rossman, G, Wilson, B. (1985). Numbers and words, Combining qualitative and quantitative methods in a single large scale evaluation study. Evaluation Review 9 (5). 627-643.

[13] Shin, JS. (2005). Developing in Two Languages: Korean Children in America. Toronto: Multilingual Matters LTD.

[14] Sudaryanto. (2015). Metode dan Teknik Analisis Bahasa. Yogyakarta: Sanatha Darma University Press.

[15] Sugiyono. (2010). Metode Penelitian Kuantitatif Kualitatif dan R\&D. Bandung: Alfabeta.

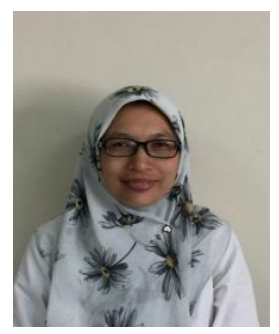

Lukia Zuraida. Born in East Java, November $10^{\text {th }}$, 1969. She graduated from State Education Institute in Surabaya, East Java, Indonesia, majoring in Japanese in 1994. She received her Master's degree from Udayana University on Linguistic in 2009. At present, she is a doctoral student in linguistics at Udayana University, Denpasar, Bali, Indonesia.

She has been working in the tourism field as a hotelier and Japanese guide. She worked at Bali Padma Hotel and Resort as Japanese guests' relation (5 years) and Sheraton Mustika Yogyakarta (2 years), and also a guide for Japanese guests. Since 2000, she is working as a lecturer in Bali Tourism Polytechnic (BTP) as a Japanese lecturer. BTP is one of the state tourism polytechnics in Indonesia located in Nusa Dua Bali, Indonesia. Her list of publications are "Kankou Nihongo", Jakarta: Raja Grafindo Persada, 2018, and "Perception of Japanese Guest toward Japanese Guide in Bali", Jurnal Kepariwisataan, Vol 13 No 2, 2014. She is also a member of ASJI (Indonesia's Japan Study Association), ASPBJI (Japanese Language Lecturer Association in Indonesia).

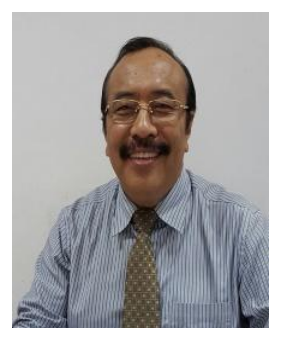

Budiarsa, Made. Born in Bali, January $7^{\text {th }}, 1953$. He graduated from Udayana University majoring in English Bachelor (1982). He gained his Master's Degree from Sydney University mastering Linguistics (1988), and Doctoral program from Gadjahmada University majoring in Linguistics (2006).

At present he is a Lecturer at the English Department, Udayana University. Currently as a COORDINATOR OF TOURISM STUDY PROGRAM at Postgraduate Program, Udayana University, Bali, Indonesia. His lists of publications are "The Power of Media Shaping Japanese women's Linguistic Behaviour". International Journal of Multidisciplinary Educational Research, Vol 6 issue 4(1). 2017., "Code Switching in Hindu Religious Preaching”, International Journal of Social Science, Vol 6 issue 2, 2016., and "Bahasa dalam Perspektif Sosial Budaya (Language in Socio-Cultural Perspective)", Bali : Swasta Nulus, 2017. He is a member of EPI-UNET (Eastern Part of Indonesia University Network (2017-present), Indonesian English Study Associations (present).

I Ketut Darma Laksana is a senior professor in Linguistics at Udayana University, Bali, Indonesia. He accomplished his master's degree in 1994 and doctoral degree in 2003 at the Linguistics Program at Indonesia University, Jakarta, Indonesia. His current interests are on issues related to cultural linguistics, morphology, and discourse analysis. He is also actively participating in national and international linguistics seminars.

I Wayan Simpen is a professor in Linguistics at Udayana University, Bali, Indonesia. He accomplished his master's degree in 1995 at the Linguistics Program at Indonesia University, Jakarta, Indonesia and doctoral degree at the Linguistics Program of Udayana University, Bali, Indonesia in 2008. His current interests are on issues related to ecolinguistics, cultural linguistics, and pragmatics. 